\title{
PENGARUH KUALITAS PELAYANAN PAJAK KENDARAAN BERMOTOR TERHADAP KEPATUHAN WAJIB PAJAK KENDARAAN BERMOTOR PADA KANTOR BADAN PENGELOLAAN PENDAPATAN DAERAH (BAPPENDA) PROVINSI NUSA TENGGARA BARAT
}

\author{
Masrun \\ Fakultas Ekonomi dan Bisnis Universitas Mataram \\ masrun@unram.ac.id \\ Muslimatun Fitriah \\ Fakultas Ekonomi dan Bisnis Universitas Mataram
}

\begin{abstract}
ABSTRAK
Penerimaan pajak merupakan pemasukan dana yang paling potensial bagi negara, karena besarnya pajak seiring dengan laju pertumbuhan penduduk, perekonomian, dan stabilitas politik karena pajak berasal dari dana masyarakat. Sedangkan penerimaan di luar pajak seperti dari sektor migas (minyak dan gas) tidak bisa diandalkan karena sesuai dengan hukum alam jika terus menerus di eksploitasi cenderung akan berkurang dan lama kelamaan akan habis pada akhirnya. Pajak adalah suatu kewajiban kenegaraan dan pengabdian serta peran aktif warga negara dan anggota masyarakat lainnya untuk membiayai keperluan negara yang berupa pembangunan nasional yang pelaksanaannya di atur dalam undang-undang dan peraturanperaturan untuk tujuan kesejahteraan bangsa dan negara. Pengeluaran utama negara untuk pengeluaran rutin seperti biaya pegawai, subsidi, utang, bunga, dan cicilannya.

Salah satu kegiatan usaha yang dapat menambah penerimaan negara adalah pajak kendaraan bermotor. Tujuan dari Praktik Kerja Lapangan (PKL) adalah untuk mengetahui kualitas unit pelayanan pajak kendaraan bermotor secara berkala pada kantor Badan Pengelolaan Pendapatan Daerah (Bappenda) Provinsi Nusa Tengga Barat tersebut sudah sesuai dengan peraturan perundang-undangan berlaku.

Kegiatan selama Praktik Kerja Lapangan (PKL) ini adalah mempelajari bagaimana Pengaruh Kualitas Pelayanan Pajak Kendaraan Bermotor Terhadap Kepatuhan Wajib Pajak Kendaraan Bermotor Pada Kantor Badan Pengelolaan Pendapatan Daerah (Bappenda) Provinsi Nusa Tengga Barat (NTB) mulai dari tanggal 03 Februari sampai dengan 02 April 2020.

Selama melaksanakan kegiatan Praktek Kerja Lapangan (PKL) pada kantor Bappenda Provinsi Nusa Tenggara Barat (NTB) ini, penulis dapat mengetahui Pengaruh Kualitas Pelayanan Pajak Kendaraan Bermotor Terhadap Kepatuhan Wajib Pajak Kendaraan Bermotor Pada Kantor Badan Pengelolaan Pendapatan Daerah (Bappenda) Provinsi Nusa Tenggara Barat (NTB). Selain itu penulis juga dapat mengetahui, serta mempraktikan langsung bagaimana mencari hubungan keterkaitan (relavan) dari teori yang di peroleh selama perkuliahan dengan kenyataan yang ada di lapangan. Bagi Kantor Bappenda Provinsi NTB untuk tetap mempertahankan dan mengikuti Peraturan Perpajakan dalam melakukan pelayanan yang baik untuk wajib pajak khususnya Pajak Kendaraan Bermotor sehingga dalam praktiknya tidak akan mengalami kesulitan.
\end{abstract}

Kata kunci: Kualitas Pelayanan, Pajak Kendaraan Bermotor, Kepatuhan Wajib Pajak 


\section{PENDAHULUAN}

Pajak adalah iuran rakyat kepada kas negara berdasarkan undang-undang (yang dapat dipaksakan) dengan tidak mendapatkan jasa timbal (kontraprestasi) yang langsung dapat ditunjukkan dan yang digunakan untuk membayar pengeluaran umum. Pajak salah satu sumber penerimaan terbesar bagi keuangan negara yang sangat berperan dalam pembiayaan negara dan pembangunan nasional, hasil dari pajak ini akan dikelola dan kemudian akan digunakan kembali oleh pemerintah untuk rakyat. Salah satu faktor yang mempengaruhi penerimaan adalah kualitas pelayanan dari kantor pajak tersebut. Semakin baik tingkat pelayanan maka akan semakin besar pula pengaruhnya terhadap peningkatan potensi dan penerimaan pajak.

Melalui modernisasi administrasi perpajakan yang mencakup reformasi pelayanan Kantor UPTB UPPD Kota Mataram adalah meningkatkan Standar Operasional Pelayanan antara lain: standar fasilitas pelayanan, standar sumber daya manusia, menerapkan etika pelayanan dan mengedepankan sikap profesional.

Kantor UPTB UPPD Kota Mataram memiliki keunggulan dalam hal kecepatan pelayanan karena proses pelayanan yang relative singkat, untuk mendukung hal tersebut Kantor UPTB UPPD Kota Mataram merealisasikan layanan unggulan guna untuk memberi kepastian, antara lain terhadap proses, jangka waktu penyelesaian, biaya dan jasa pelayanan, dan persyaratan administrasi yang digunakan sebagai acuan pelayanan publik.

Pelayanan publik oleh aparatur pemerintah dewasa ini masih banyak dijumpai kelemahan sehingga belum dapat memenuhi kualitas yang diharapkan masyarakat. Hal ini ditandai dengan masih adanya keluhan masyarakat yang disampaikan melalui media massa, sehingga dapat menimbulkan citra yang kurang baik terhadap aparatur pemerintah. Mengingat fungsi utama pemerintah adalah melayani masyarakat. Hal ini sejalan dengan amanat UU Nomor 25 Tahun 2009 tentang Pelayanan Publik, dimana pelayanan masyarakat harus memenuhi standarisasi yang diatur dalam ketentuan tersebut.

Dalam rangka peningkatan kualitas pelayanan publik khususnya pelayanan kepada masyarakat dalam hal pembayaran Pajak Kendaraan Bermotor (PKB) diperlukan adanya perubahan-perubahan, terutama restrukturisasi tim strategi pelayanan. Strategi ini diharapkan dapat mendongkrak peningkatan kinerja pegawai yang akhirnya akan menghasilkan outcome yang memuaskan yang dapat dilihat dari hasil survei, untuk itulah UPTB UPPD kota Mataram secara rutin melakukan survey terhadap kepuasan masyarakat terkait kualitas layanan yang diberikan.

\section{TUJUAN}

1. Untuk mengetahui pengaruh kualitas unit pelayanan secara berkala dan sebagai bahan menetapkan kebijakan pelayanan publik dalam rangka peningkatan kualitas mutu pelayanan selanjutnya.

2. Untuk meningkatkan unit pelayanan yang baik bagi wajib pajak 


\section{TELAAH LITERATUR DAN PENGEMBANGAN HIPOTESIS}

\section{Definisi pajak}

Menurut Undang-Undang Nomor 16 Tahun 2009 tentang perubahan ke-empat Undang-Undang Nomor 6 Tahun 1983 tentang ketentuan Umum dan Tata Cara Perpajakan pada Pasal 1 Ayat 1 berbunyi pajak adalah kontribusi wajib kepada Negara yang teutang oleh orang pribadi atau badan yang bersifat memaksa berdasarkan undang-undang, dengan tidak mendapatkan imbalan secara langsung dan digunakan untuk keperluan negara bagi sebesar-besarnya kemakmuran rakyat.

Berikut Pajak menurut para ahli (Siti Resmi, 2007) adalah:

1. Rochmat Soemitro

Pajak adalah iuran rakyat kepada kas Negara berdasarkan undang-undang (yang dapat dipaksakan) dengan tidak mendapat jasa timbal balik (kontraprestasi) yang langsung dapat ditunjukkan dan yang digunakan untuk membayar pengeluaran umum.

2. S.I Djajadiningrat

Pajak sebagai suatu kewajiban menyerahkan sebagai dari kekayaan ke kas negara yang disebabkan suatu keadaan, kejadian, dan perbuatan yang memberikan kedudukan tertentu, tetapi bukan sebagai hukuman, menurut peraturan yang ditetapkan pemerintah serta dapat dipaksakan, tetapi tidak ada jasa timbal balik dari Negara secara langsung untuk memelihara kesejahteraan secara umum.

3. N.J. Feldman

Pajak adalah prestasi yang dipaksakan sepihak oleh dan terutang kepada penguasa (menurut norma-norma yang di tetapkannya secara umum), tanpa adanya kontraprestasi, dan semata-mata digunakan untuk menutup pengeluaranpengeluaran.

Dari definisi tersebut, dapat disimpulkan bahwa pajak memiliki unsur-unsur menurut (Mardiasmo, 2018) sebagai berikut:

1. Iuran dari rakyat kepada Negara, yang berhak berdasarkan pajak hanyalah Negara. Iuran tersebuat berupa uang (bukan barang)

2. Berdasarkan undang-undang. Pajak dipungut berdasarkan atau dengan kekuatan undang-undang serta aturan pelaksanaanya.

3. Tanpa jasa timbal atau kontraprestasi dari Negara yang secara langsung dapat ditunjuk. Dalam pembayaran pajak tidak dapat ditunjukkan adanya kontraprestasi individual oleh pemerintah.

4. Digunakan untuk membiayai rumah tangga Negara, yaitu pengeluaranpengeluaran yang bermanfaat bagi masyarakat luas.

\section{Fungsi Pajak}

Pajak memiliki fungsi yang sangat strategis bagi berlangsungnya suatu negara menurut (Siti Resmi, 2017) antara lain memiliki fungsi sebagai berikut:

a. Fungsi Anggaran (Budgetair)

Pajak berfungsi sebagai salah satu sumber dana bagi pemerintah untuk membiayai pengeluaran-pengeluarannya.

b. Fungsi Mengatur (Regulerend)

Pajak berfungsi sebagai alat untuk mengatur atau melaksanakan kebijaksanaan pemerintah dalam bidang sosial dan ekomomi

c. Fungsi Stabilitas

Pajak sebagai penerimaan Negara dapat digunakan untuk menjalankan kebijakankebijakan pemerintah

d. Fungsi Redristribusi Pendapatan (pemerataan) 
Penerimaan Negara dari pajak digunakan untuk membiayai pengeluaran umumdan pembangunan nasional sehingga dapat membuka kesempatan kerja dengan tujuan untuk meningkatan pendapatan masyarakat.

\section{Jenis Pajak}

\section{Pengelompokkan Pajak} yaitu:

Pajak dapat dikelompokkan kedalam tiga kelompok menurut (Siti Resmi, 2017)

1. Menurut golongannya, Pajak dapat dibagi menjadi:

a. Pajak Langsung, yaitu pajak yang harus dipikul atau ditanggung sendiri oleh wajib pajak dan tidak dapat dilimpahkan atau dibebankan kepada orang lain atau pihak lain.

Contoh: Pajak Penghasilan (PPh)

b. Pajak Tidak Langsung, yaitu pajak yang pada akhirnya dapat dibebankan atau dilimpahkan kepada orang lain atau pihak ketiga.

Contoh: Pajak Pertambahan Nilai (PPN)

2. Menurut Sifatnya

a. Pajak Subjektif, yaitu pajak yang pengenaanya memperhatikan keadaan pribadi wajib pajak atau pengenaan yang memperhatikan keadaan subjektifnya.

Contoh: Pajak Penghasilan (PPh)

b. Pajak Objektif, yaitu pajak yang pengenaanya memperhatikan objeknya. Contoh Pajak Pertambahan Nilai (PPN) dan Pajak Penjualan atas Barang Mewah (PPnBM)

\section{Menurut Pemungutannya}

1. Pajak Pusat, yaitu pajak yang dipungut oleh pemerintah pusat dan digunakan untuk membiayai Rumah Tangga Negara.

Contohnya:

a. Pajak Penghasilan (PPh) adalah setiap tambahan kemampuan ekonomis yang ditrima atau diperoleh Wajib Pajak, baik yang berasal dari Indonesia maupun dari luar Indonesia, yang dapat dipakai untuk konsumsi atau untuk menambah kekayaan Wajib Pajak yang bersangkutan, dengan nama dan dalam bentuk apapun. (Undang-Undang Pajak Penghasilan UU Nomor 36 Tahun 2008, pasal:4)

b. Pajak Pertambahan Nilai (PPN) adalah pajak yang dikenakan atas pertambahan nilai dari barang atau jasa dari produsen ke konsumen. (Undang-Undang Nomor 42 Tahun 2009)

c. Pajak Penjualan Barang Mewah (PPnBM) adalah pajak yang dikenakan atas barang yang tergolong mewah, disamping dikenai Pajak Pertambahan Nilai, dikenai juga Pajak Penjualan atas Barang Mewah. Dimana Barang Kena Pajak yang tergolong mewah adalah barang yang bukan merupakan barang kebutuhan pokok, barang yang dikonsumsi oleh masyarakat tertentu, barang yang pada umumnya dikonsumsi oleh masyarakat berpenghasilan tinggi, dan/atau barang yang dikonsumsi untuk menunjukkan status. (Undang-Undang Nomor 42 Tahun 2009)

d. Pajak Bumi \& Bangunan (PBB) aalah pajak kebendaan atas bumi dan/atau bangunan yang dikenakan terhadap orang pribadi atau badan yang secara nyata mempunyai hak dan/atau memperoleh manfaat atas bumi dan/atau memiliki, menguasai dan/atau memperoleh manfaat atas bangunan. PBB merupakan pajak kebendaan, dalam arti besarnya pajak terutang ditentukan oleh keadaan objek yaitu bumi/tanah dan/atau bangunan, sedangkan keadaan subjeknya (siapa yang membayar) tidak ikut menentukan besarnya pajak. (Pelatihan Pajak Terapan Brevet AB Terpadu, Hal: 429 dan Undang-Undang Nomor 12 Tahun 1994) 
e. Bea Perolehan Ha katas Tanah/Bangunan (BPHTB) adalah pajak yang dikenakan atas perolehan ha katas tanah dan/atau bangunan. (Perpajakan, Mardiasmo edisi revisi 2006, Hal : 324 dan Undang-Undang Nomor 20 Tahun 2000)

f. Bea Materai adalah pajak yang dikenakan atas dokumen, benda materai, tanda tangan, pemeteraian kemudian dan pejabat pos. (Undang-Undang Nomor 13 Tahun 1985, Pasal : 1)

2. Pajak Daerah, yaitu pajak yang dipungut oleh pemerintah daerah dan digunakan untuk membiayai rumah tangga daerah. Contohnya:

a. Pajak Daerah dari pemerintah Provinsi adalah Pajak Kendaraan Bermotor dan kendaraan di atas air, Bea Balik Nama Kendaraan Bermotor \& kendaraan di atas air. Pajak Bahan Bakar Kendaraan Bermotor, Pajak Pengambilan dan Pemanfaatan Air dan Bawah Tanah dan Air Permukaan.

b. Pajak Daerah dari Pemerintah Kabaupaten/Kota adalah Pajak Hotel, Pajak Restoran, Pajak Hiburan, Pajak Reklame, Pajak Penerangan Jalan, Pajak Pengambilan Bahan Galian, dan Pajak Parkir.

\section{Asas Pemungutan Pajak}

Dalam asas pemungutan pajak dikenal beberapa sistem pemungutan menurut (Mardiasmo, 2018:9) yaitu:

1. Asas Domisili (Asas Tempat Tinggal)

Negara berhak mengenakan pajak atas seluruh penghasilan Wajib Pajak ysng bertempat tinggal di wilayahnya, baik penghasilan yang berasal dari dalam maupun luar negeri. Asas ini berlaku untuk Wajib Pajak dalam negeri.

2. Asas Sumber

Negara berhak mengenakan pajak atas penghasilan yang bersumber di wilayahnya tanpa memperhatikan tempat tinggal Wajib Pajak.

3. Asas Kebangsaan

Pengenaan pajak dihubungkan dengan kebangsaan suatu Negara.

\section{Sistem Pemungutan Pajak}

Dalam memungut pajak dikenal beberapa sistem pemungutan menurut (Mardiasmo, 2018:9) yaitu:

1. Official Assessment System

Adalah suatu sistem pemungutan yang memberi wewenang kepada pemerintah (fiskus) untuk menentukan besarnya pajak yang terutang oleh Wajib Pajak. Cirinyacirinya:

a. Wewenang untuk menentukan besarnya pajak terutang ada pada fiskus.

b. Wajib pajak bersifat pasif.

c. Utang pajak timbul setelah dikeluarkan surat ketetapan pajak oleh fiskus.

2. Self Assessment System

Adalah suatu sistem pemungutan pajak yang memberi wewenang kepada kepada Wajib Pajak untuk menetukan sendiri besarnya pajak yang terutang. Ciri-cirinya:

a. Wewenang untuk menentukan besarnya pajak terutang ada pada Wajib Pajak sendiri.

b. Wajib Pajak aktif mulai dari menghitung, menyetor, dan melaporkan sendiri pajak yang terutang,

c. Fiskus tidak ikut campu dan hanya mengawasi.

3. Withholding System

Adalah suatu sistem pemungutan pajak yang memberi wewenang kepada pihak ketiga (bukan fiskus dan bukan Wajib Pajak yang bersangkutan) untukmemotong atau memungut pajak yang terutang oleh Wajib Pajak. 


\section{Pajak Daerah}

\section{Pengertian Pajak Daerah}

Secara umum, pajak adalah iuran wajib anggota masyarakat kepada Negara karena Undang-Undang dan atas pembayaran tersebut pemrintah tidak memberikan balas jasa yang langsung dapat di tunjukkan dalam konteks daerah.

Pajak daerah adalah pajak yang di pungut oleh Pemerintah Daerah (Provinai, Kabupaten, Kota) yang di atur berdasarkan peraturan daerah masing-masing dan hasil pemungutannya digunakan untuk pembiayaan rumah tangga daerah. Sedangkan menurut Undang-Undang No.18 tahun 1997 tentang Pajak Daerah dan Retribusi Daerah Daerah sebagaimana di ubah terakhir dengan Undang-Undang No. 28 tahun 2009, Pajak Daerah adalah kontribusi wajib kepada daerah yang terutang oleh orang pribadi atau badan yang bersifat memaksa berdasarkan Undang-Undang, dengan tidak mendapatkan imbalan secara langsung dan digunakan untuk keperluan daerah bagi sebesar-besarnya kemakmuan rakyat. Pajak daerah dapat dipakasakan berdasarkan peraturan perundang-undang yang berlaku, dimana hasilnya digunakan untuk membiayai penyelenggaraan pemerintah dan pembangunan daerah.

\section{Pembagian Pajak Daerah}

Pembagian pajak daerah (Mardiasmo, 2018:15) meliputi:

1. Pajak Provinsi, yaitu iuran wajib yang dilakukan oleh pemerintah daerah provinsi kepada orang pribadi atau badan tanpa imbalan langsung yang seimbang yang dapat dipaksakan berdasarkan peraturan perundang-undangan yang berlaku, yang digunakan untuk membiayai penyelenggaraan pemerintah daerah provinsi sebatas pemberian kewenangan untuk melaksanakan otonomi daerah masing-masing.

Adapun termasuk pajak provinsi sebagai berikut:
a. Pajak Kendaraan Bermotor
b. Bea Balik Nama Kendaraan Bermotor
c. Pajak Bahan Bakar Minyak Kendaraan Bermotor
d. Pajak Air Permukaan
e. Pajak Rokok

2. Pajak Kabupaten/Kota yaitu, iuran wajib yang dilakukan oleh pemerintah daerah kabupaten/kota kepada orang pribadi atau badan tanpa imbalan langsung yang seimbang, yang dapat dipaksakan berdasarkan peraturan perundang-undangan yang berlaku, dan digunakan untuk membiayai penyelenggara pemerintah daerah atau kabupaten/kota sebatas pemberian kewenangan untuk melaksanakan otonomi daerah.

Yang termasuk Pajak Kabupaten/Kota sebagai berikut:
a. Pajak Hotel dan Restoran
b. Pajak Hiburan
c. Pajak Reklame
d. Pajak Penerangan Jalan
e. Pajak Parkir
f. Pajak Air Mineral Bukan Logam dan Bangunan
g. Pajak Air Tanah
h. Pajak Sarang Burung Walet
i. Pajak Bumi dan Bangunan Perdesaan dan Perkotaan
j. Bea Perolehan Hak Atas Tanah dan Bangunan.

\section{Pajak Kendaraan Bermotor (PKB) \\ Pengertian Pajak Kendaraan Bermotor}

Salah satu Pajak Provinsi yang berlaku di Indonesia adalah Pajak Kendaraan Bermotor (PKB). Menurut Undang-Undang Nomor 28 Tahun 2009 tentang Pajak Daerah dan Retribusi Daerah Pasal 1 ayat (12) dan ayat (13) Pajak Kendaraan 
Bermotor (PKB) merupakan pajak yang dikeakan terhadap kepemilikkan dan atau penguasaan kendaraan bermotor.

Kendaraan bermotor adalah semua kendaraan beroda dua atau lebih beserta gandengannya yang digunakan di semua jenis jalan darat dan digerakkan oleh peralatan teknis berupa mobil atau peralatan lainnya yang berfungsi untuk mengubah suatu sumber daya energy tertentu menjadi tenaga gerak kendaraan bernotor yang bersangkutan, termasuk alat-alat berat dan alat-alat besar yang bergerak.

\section{Dasar Hukum Pajak Kendaraan Bermotor}

a. Undang-Undang Nomor Tahun 2009 tentang Pajak Daerah dan Retribusi Daerah

b. Perda Provinsi NTB Nomor 9 Tahun 2017 tentang Pajak Daerah

c. Pergub Provinsi NTB Nomor 22 Tahun 2017 tentang Perhitungan Dasar Pengenaan PKN dan BBnKB

\section{Objek Pajak Kendaraan Bermotor}

Objek kendaraan bermotor adalah suatu yang dapat dijadikan sasaran pengenaan pajak. Sesuatu tersebut dapat berupa keadaan perbuatan, dan peristiwa. Karena Pajak Kendaraan Bermotor termasuk pajak obyektif atau kebendaan, maka yang menjadi objek pajak adalah keadaan benda tersebut. Menurut Undang-Undang N0mor 2008 Tahun 2009 tentang Pajak Daerah dan Retribusi Daerah Pasal 3 ayat (1) dan ayat (2) yang dimaksud Objek Pajak Kendaraan Bermotor adalah kepemilikkan dan/atau penguasa kendaraan bermotor oleh orang pribadi atau badan. Termasuk dalam pengertian Kendaraan Bermotor adlah kendaraan bermotor beroda beserta gandengannya, yang dioperasikan di semua jenis jalan darat dan kendaraan bermotor yang dioperasikan di air dengan ukuran isi kotor GT 5 (Lima Gross Tonnage) sampai dengan GT 7 (Tujuh Gross Tonnage).

\section{Pengecualian Objek Pajak Kendaraan Bermotor}

Menurut Undang-Undang Nomoe 38 Tahun 2009 tentang Pajak Daerah dan Retribusi Daerah Pasal 3 Ayat (3) yamg dikecualikan sebgai Objek Pajak Kendaraan Bermotor adalah:

1. Kareta Api

2. Kendaraan Bermotor yang semata-mata digunakan untuk keperluan pertahanan dan keamanan Negara

3. Kendaraan Bermotor yang dimiliki dan/atau dikuasai keduataan, konsulat, perwakilan Negara asing dengan asas timbal balik dan lembaga-lembaga internasional yag memperoleh fasilitas pembebasan pajak dari pemerintah; dan

4. Objek Pajak lainnya ditetapakan dalam Peraturan Daerah.

\section{Subjek Pajak Kendaraan Bermotor (PKB) dan Wajib Pajak Kendaraan Bermotor}

Pasal 4 Undang-Undang Nomor 282009 mengatur bahwa subhek pajak kendaraan bermotor adalah orang pribadi atau badan yang memiliki dan/atau menguasai kendaraan bermotor. Wajib pajak kendaraan bermotor adalah orang pribadi atau badan yang memiliki kendaraan bermotor. Bagi wajib pajak yang berupa suatu badan maka kewajiban perpajakannya diwakili oleh pengurus atau kuasa dari badan tersebut.

\section{Dasar Pengenaan Pajak Kendaraan Bermotor (PKB)}

Dasar pengenaan Pajak Kendaraan Bermotor adalah hasil perkalian dari 2 (dua) unsur:

a. Nilai Jual Kendaraan Bermotor

b. Bobot yang mencerminkan secar realtif tingkat kerusakan jalan dan/atau pencemaran lingkungan akibat penggunaan Kendaraan Bermotor.

Khusus untuk Kendaraan Bermotor yang digunakan di luar jalan umum, termasuk alat-alat berat dan alat-alat besar serta kendaraan di air, dasr pengenaan Pajak Kendaraan Bermotor adalah Nilai Jual Kendaraan Bermotor. Bobot sebagaimana 
dimaksud dinyatakan dalam koefisien yang nilainya 1 (satu) atau lebih besar 1 (satu), dengan pengertian sebagai berikut:

a. Koefisien sama dengan 1 (satu) berarti kerusakan jalan dan/atau pencemaran lingkungan oleh pengguna Kendaraan Bermotor tersebut dianngap masih dalam batas toleransi.

b. Koefisien lebih besar dari 1 (satu) berarti pengguna Kendaraan Bermotor tersebut di anggap melewati batas toleransi

Faktor-Faktor Yang Mempengaruhi Kepatuhan Pajak Kendaraan Bermotor Dalam Kaitannya Dengan Kualitas Pajak Kendaraan Bermotor

Untuk mencapai tingkat kepatuhan Wajib Pajak dan mempertahankan tingkat kepatuhan saat ini merupakan isu yang menjadi perhatian para pembuat kebijakan baik di negara maju maupun berkembang. Bahwa salah satu masalah yang paling serius bagi para pembuat kebijakan ekonomi adalah mendorong tingkat kepatuhan wajib pajak. Hali ini dikarenakan tingkat kepatuhan untuk belanja. Keatuhan wajib pajak merupakan faktor penting bagi pningkatan pajak, maka perlu secara intensif dikaji tentang faktor-faktor yang mempengaruhi kepatuhan wajib pajak, khususnya dalam membayar pajak kendaraan bermotor di unit pelayanan UPTB UPPD di Provinsi Nusa Tenggara Barat.

Adapun faktor-faktor yang mempengaruhi kepatuhan membayar Pajak Kendaraan Bermotor dalam kaitannya dengan pengaruh kwalitas Pajak Kendaraan Bermotor sebagai berikut:

1. Faktor Kesadaran Masyakat

Kesadaran masyarakat yang tinggi akan mendorong semakin banyak masyarakat memenuhi kewajibannya untuk mendaftarkan diri sebagai wajib pajak, melaporkan dan membayar pjaknya dengan benar sebagai wujud tanggung jawab berbangsa dan bernegara. Apabila kesadaran masyarakat atas perpajakan masih rendah maka akan menyebabkan banyaknya potensi pajak yang tidak dapat dijaring, kesadaran wajib pajak berpengaruh positif pada kepatuhan pelaporan wajib pajak orang pribadi.

2. Faktor Meningkat Kewajiban Moral Wajib Pajak

Satu karakteristik yang berbeda adalah adanya perasaan bersalah yang dimiliki oleh satu oihak namun tidak memiliki oleh pihak lain, inilah norma individu atau kewajiban moral. Kewajiban moral merupakan norma individu yang dimiliki seseorang dalam melaksanakan sesuatu. Dimana tingkat kepatuhan pajak akan menjadi tinggi ketika wajib pajak memiliki kewajiban moral yang lebih kuat.

3. Faktor Pengetahuan Tentang Pajak

Faktor pengetahuan sangat penting dalam membantu wajib pajak melaksanakan kewajibannya, khususnya pengetahuan dasar tentang perpajakan tanpa adanya pengetahuan, wajib pajak akan mengalami kesulitan dalam mendaftarkan diri, mengisi fotmulir, membayar dan melaporkan kewajiaban perpajakannya.

Beberapa faktor lainya seperti pelayanan fiskus dalam melayani kebutuhan wajib pajak, sosialisasi mengenai perpajakn, persepi atas penggunaan uang pajak secara transparan memiliki kemungkinan mempengaruhi kepatuhan wajib pajak dalam melaksanakan kewajibannya sebagai warga Negara. Untuk meningkatkan kepatuhan wajib pajak dalam memenuhi kewajiban perpajakannya, kualitas pelayanan pajak harus ditingkatkan oleh aparat pajak, oleh karena itu kualitas pelayanan perlu ditingkatkan untuk memberikan kenyamanan dan pandangan yang baik dari wajib pajak. Pelayanan petugas pajak yang kooperaif, jujur, menegakkan aturan perpajakan, tidak mempersulit, dan tidak mengecewakan wajib pajak diharapkan mampu mengatasi masalah kepatuhan wajib pajak. Keramah-tamahan petugas pajak dan kemudahan dalam sistem informasi perpajakan termasuk dalam pelayanan perpajakan 
tersebut. Pemerintah terus meningkatkan kualitas pelayanan yang di berikan kepada wajib pajak dengan membuat sistem pendukung. Hal ini diharapkan dapat memudahkan wajib pajak dalam membayar dan melaporkan kewajiban pajaknya. Agar kemudahan dari sistem perpajakan dapat berjalan dengan baik dan dimengerti masyarakat, sosialisasi tersebut masyarakat akan lebih memahami masalah-masalah seputar perpajakan, kemudahan yang bisa didapat dan memahami perarturan yang berubah-ubah.

\section{Mekanisme Pelaksanaan Survei Kepuasan Masyarakat Terhadap Pelayanan Pajak Metode dan Unsur Survei}

Penyusunan nilai Indeks Kepuasan Masyarakat (IKM) didasarkan pada hasil Survei Kepuasan Masyarakat Terhadap Pelayanan Publik Tahun 2017. Metode survei masih mengacu kepada SK Menpan No. Kep/25/M.Pan/2/2004 tentang Pedoman Umum Penyusunan Indeks Kepuasan Masyarakat Unit Pelayanan Instansi Pemerintah. Metode ini meliputi unsur layanan, ukuran sampel, teknik mengumpulan data dan analisis data. Survei kepuasan masyarakat dilakukan secara periodik mempergunakan pendekatan metode kualitatif dengan pengukuran menggunakan Skala Likert. Skala Likert adalah suatu skala psikometrik yang umum digunakan dalam kuesioner (angket), dan merupakan skala yang paling banyak digunakan dalam riset berupa survei. Skala Likert adalah skala yang dapat dipergunakan untuk mengukur sikap, pendapat, dan persepsi seseorang atau sekelompok orang terhadap suatu jenis layanan publik. Pada skala Likert responden diminta untuk menentukan tingkat persetujuan mereka terhadap suatu pernyataan dengan memilih salah satu dari pilihan yang tersedia.

\section{Pengumpulan Data}

Survey IKM diperlukan untuk mengetahui tingkat kepuasan masyarakat secara berkala dan mengetahui kecendrungan kinerja pelayanan pada masing-masing unit kerja pelayanan Bappenda Prov. NTB. Komponen ini berkaitan dengan pelaksanaan survey IKM, metode yang digunakan, skors yang diperoleh serta tindak lanjut dari hasil pelaksanaan survey IKM tersebut. Berdasarkan prinsip pelayanan sebagaimana telah ditetapkan dalam keputusan Menteri PAN Nomor: 63/KEP/M.PAN/2003, yang dikemudian dikembangkan menjadi 14 unsur yang relevan, valid dan reliable sebagai unsur minimal yang harus ada untuk dasar pengukuran indeks kepuasan masyarakat adalah sebagai berikut:

1. Prosedur pelayanan yaitu, kemudahan tahapan pelayanan yang diberikan kepada masyarakat dilihat dari sisi kesederhanaan alur pelayanan;

2. Persyaratan pelayanan yaitu, persayaratan teknis dan administrative yang diperlukan mendapatkan pelayanan sesuai dengan jenis pelayanannya. Kejelasan petugas pelayanan, yaitu keberadaan dan kepastian petugas yang memberikan pelayanan (nama, jabatan, kewenangan dan tanggungjawabnya);

3. Kedisiplinan petugas pelayanan, yaitu kesungguhan petugas dalam memberikan pelayanan terutama terhadap konsistensi waktu kerja sesuai ketentuan yang berlaku;

4. Tanggungjawab petugas pelayanan, yaitu kejelasan wewenang dan tanggungjawab petugas dalam penyelenggaraan dan penyelesaian pelayanan;

5. Kemampuan petugas pelayanan yaitu, tingkat keahlian dan keterampilan yang dimiliki petugas dalam memberikan /menyelesaikan pelayanan kepada masyarakat;

6. Kecepatan pelayanan, yaitu target waktu pelayanan dapat diselesaikan dalam waktu yang telah ditentukan oleh unit penyelenggara pelayanan;

7. Keadilan mendapatkan pelayanan, yaitu pelaksanaan pelayanan dengan tidak membedakan golongan/status masyarakat yang dilayani; 
8. Kesopanan dan keramahan petugas, yaitu sikap dan perilaku petugas dalam memberikan pelayanan kepada masyarakat secara sopan dan ramah serta saling menghargai dan menghormati.

\section{Penetapan Jumlah responden}

Untuk akurasi hasil yang didapatkan jumlah responden yang disurvey minimal 150 orang dari jumlah populasi penerima pelayanan, dengan dasar (Jumlah Unsur +1 ) x 10 atau $(14+1) \times 10=150$ responden. Namun untuk tahapan semester I dikumpulkan sebanyak 15 responden per bulan, dan sepanjang semester I telah dikumpulkan sebanyak 75 responden, sedangkan selebihnya akan diselesaikan dalam semester II.

\begin{tabular}{|l|l|l|}
\hline BOBOT NILAI RATA-RATA & JUMLAH BOBOT & $=1 / 4=0,071$ \\
\cline { 2 - 2 } TERTIMBANG $=$ & JUMLAH UNSUR & \\
\hline
\end{tabular}

\section{Pengolahan Data Data}

Yang telah terkumpul kemudian diolah untuk mengetahui nilai Indeks Kepuasan Masyarakat (IKM). Nilai IKM yang didapatkan dari rata-rata tertimbang masingmasing ke-14 unsur pelayanan. Setiap unsur pelayanan memiliki penimbang yang sama dengan rumus. Selanjutnya untuk mendapatkan nilai IKM dilakukan penghitungan dengan rumus sebagai berikut:

\section{\begin{tabular}{l|l|l|l|} 
IKM = & $\begin{array}{l}\text { Total dari Nilai Persepsi per } \\
\text { Unsur } \\
\text { Total Unsur yang terisi }\end{array}$ & $\begin{array}{l}\text { Xilai } \\
\text { Penimbang }\end{array}$ \\
\hline
\end{tabular}}

Untuk memudahkan interprestasi terhadap penilai IKM yaitu antara 25 - 100 maka hasil penilaian tersebut di atas dikonvensikan dengan nilai dasar 25 dengan rumus sebagai berikut:

\section{IKM Hasil Penilaian x 25}

\section{HASIL PENELITIAN DAN PEMBAHASAN}

\section{Cara Pemungutan}

1. Cara pemungutan ialah :

a. Pemungutan pajak tidak dapat di borongkan

b. Pajak dipungut berdasarkan penetapan oleh Badan Pengelolaan Pendapatan Daerah atau yang ditunjuk

c. Pajak dipungut berdasarkan penetapan oleh Badan Pengelolaan Pendapatan Daerah atau yang ditunjuk.

\section{Perkembangan pendapatan}

Perkembangan pendapatan daerah untuk pajak kendaraan bermotor selama 5 tahun dari 2015-2019. 
Data Pajak Kendaraan Bermotor

\begin{tabular}{c|l|l}
\hline No & \multicolumn{1}{|c|}{ Tahun } & \multicolumn{1}{c}{ Jumlah } \\
\hline 1 & 2015 & 240.153 .372 .762 \\
\hline 2 & 2016 & $269.187 .973 .631,00$ \\
\hline 3 & 2017 & $324.423 .070 .254,00$ \\
\hline 4 & 2018 & $389.092 .415 .685,00$ \\
\hline 5 & 2019 & $437.057 .973 .846,00$ \\
\hline
\end{tabular}

Dari data diatas bisa di lihat bahwa perkembangan pelayanan selama 5 tahun mengalami kenaikan

\section{Karakteristik Responden}

Karakteristik responden pada survey IKM UPTB-UPPD Mataram meliputi karakteristik menurut umur, jenis kelamin, pendidikan dan pekerjaan utama. Data lengkap karakteristik responden tercantum pada Lampiran tersendiri. Pembahasan lebih lanjut tentang karakteristik responden berdasarkan 4 (empat) kategori tersebut adalah sebagai berikut:

Tabel 1. Karakteristik Responden Berdasarkan Umur

\begin{tabular}{c|cc|c|c}
\hline \multirow{2}{*}{ No } & \multicolumn{2}{|c|}{$\begin{array}{c}\text { Kategori umur } \\
\text { (tahun) }\end{array}$} & \multicolumn{2}{c}{ Jumlah responden } \\
\cline { 3 - 5 } & & (orang) & $\mathbf{( \% )}$ \\
\hline 1 & $\leq 35$ & 25 & 33,33 \\
\hline 2 & $36-45$ & 26 & 34,67 \\
\hline 3 & $46-60$ & 21 & 28,00 \\
\hline 4 & $\geq 60$ & & 3 & 4,00 \\
\hline & & Jumlah Total & $\mathbf{7 5}$ & $\mathbf{1 0 0 , 0 0}$ \\
\hline
\end{tabular}

Dari tabel diatas dapat dilihat bahwa rsponden atau pengguna jasa layanan UPTB-UPPD Mataram pada semester 1 paling dominan berada pada kelompok 36-45 tahun $(34,64 \%)$ disusul pada kategori umur $<35$ tahun $(33,33 \%)$, kemudian kelompok umur 46-60 tahun 928,00\%) sedangkan kelompok umur $\geq 60$ tahun menempati proporsi yang paling sedikit yaitu 4,00\%.

Dari proporsi tersebut dapat dilihat bahwa masyarakat pengguna jasa / wajib pajak kendaraan bermotor yang dilayani merata sampai pada umur 60 tahun, menunjukkan bahwa wajib pajak tidak hanya dari kalangan generasi muda tapi juga oleh mereka yang telah berusia lanjut.

Tabel 2. Karakteristik Responden Berdasarkan Jenis Kelamin

\begin{tabular}{c|l|l|l}
\hline \multirow{2}{*}{ No } & \multicolumn{2}{|c|}{ Kategori kelamin } & \multicolumn{2}{c}{ Jumlah Responden } \\
\cline { 3 - 4 } & & \multicolumn{2}{|c}{ (orang) } \\
\hline 1 & Laki-laki & 49 & 65,33 \\
\hline 2 & Perempuan & 26 & 34,67 \\
\hline & Jumlah Total & $\mathbf{7 5}$ & $\mathbf{1 0 0 , 0 0 0}$ \\
\hline
\end{tabular}

Responden laki-laki dominan sebagai pengguna jasa pada UPTB-UPPD Mataram pada Semester I yaitu sebesar $65,33 \%$ sedangkan responden perempuan hanya sebanyak 34,67\%. Hal ini menunjukkan bahwa masyarakat pengguna jasa / wajib Pajak Kendaraan Bermotor yang dilayani tidak hanya didominasi oleh kaum laki-laki saja, tetapi juga telah dilakukan oleh wajib pajak perempuan. 
Tabel 3. Karakteristik Responden Berdasarkan Pendidikan

\begin{tabular}{|c|c|c|c|}
\hline \multirow{2}{*}{ No } & \multirow{2}{*}{ Kategori Pendidikan } & \multicolumn{2}{|c|}{ Jumlah Responden } \\
\hline & & (orang) & $(\%)$ \\
\hline 1 & $\leq \mathrm{SD}$ & 0 & 0,00 \\
\hline 2 & SLTP & 7 & 9,33 \\
\hline 3 & SLTA sederajat & 43 & 57,33 \\
\hline \multirow[t]{2}{*}{4} & Sarjana (S1) dan Magister (S2) & 25 & 33,33 \\
\hline & Jumlah Total & 75 & 100,00 \\
\hline
\end{tabular}

Dari Tabel 4 dapat dilihat bahwa pada Semester I responden dengan pendidikan SLTA sederajat mendominasi (57,33\%), diikuti dengan kelompok pendidikan S1 dan S2 (33,33\%) dan SLTP (9,33\%). Dapat disimpulkan bahwa pengguna jasa layanan Kesamsatan pada UPTB-UPPD Kota Mataram memiliki pendidikan yang cukup tinggi yaitu sampai tingkat S2.

Tabal 4. Karakteristik Responden Bedasarkan Pekerjaan Utama

\begin{tabular}{l|l|l|l}
\hline \multirow{2}{*}{ No Kategori Pekerjaan } & \multicolumn{2}{|c}{$\begin{array}{c}\text { Jumlah } \\
\text { Responden }\end{array}$} \\
\cline { 3 - 4 } & \multirow{2}{*}{ (orang) } & \multicolumn{2}{|c}{ (\%) } \\
\hline 1 & Swasta & 19 & 25,33 \\
\hline 2 & ASN & 16 & 21,33 \\
\hline 3 & Wira Usaha & 16 & 21,33 \\
\hline 4 & Lainnya & 24 & 32,33 \\
\hline & Jumlah Total & $\mathbf{7 5}$ & $\mathbf{1 0 0 , 0 0 0}$ \\
\hline
\end{tabular}

Sebanyak 32,00\% responden memiliki pekerjaan utama pada kategori lain-lain. Kelompok pekerjaan karyawan Swasta di tempat kedua $(25.33 \%)$, selanjutnya kelompok Wajib Pajak ASN dan kelompok Wira Usaha dengan jumlah yang sama yakni $21,33 \%$. Informasi jenis pekerjaan responden bermanfaat dalam memahami kemampuan ekonomi dan ekspektasi serta persepsi masyarakat pengguna jasa layanan pada UPTB-UPPD Kota Mataram.

\section{Nilai Rata-rata Unsur Pelayanan}

Nilai Persepsi, Mutu Pelayanan dan Kinerja Unit Pelayanan

\begin{tabular}{l|c|c|l|l}
\hline $\begin{array}{c}\text { Nilai } \\
\text { Persepsi }\end{array}$ & $\begin{array}{c}\text { Nilai } \\
\text { Interval }\end{array}$ & $\begin{array}{c}\text { Nilai Interval } \\
\text { konversi }\end{array}$ & $\begin{array}{c}\text { Mutu } \\
\text { Pelayanan }\end{array}$ & $\begin{array}{c}\text { Kinerja Unit } \\
\text { Pelayanan }\end{array}$ \\
\hline 1 & $1,00-1,75$ & $25-43,75$ & D & Tidak baik \\
\hline 2 & $1,76-2,50$ & $43,76-62,50$ & $\mathrm{C}$ & Kurang baik \\
\hline 3 & $2,51-3,25$ & $62,51-81,25$ & $\mathrm{~B}$ & Baik \\
\hline 4 & $3,26-4,00$ & $81,26-100,00$ & $\mathrm{~A}$ & Sangat baik \\
\hline
\end{tabular}

Dengan nilai persepsi mutu pelayanan sebesar 90,45 pada Semester I, apabila dilihat dari tabel di atas maka dapat dikatakan Kinerja Unit Pelayanan dan Mutu Pelayanan pada UPTB-UPPD Kota Mataram adalah "A" (Sangat Baik). Kedepan kualias pelayanan ini akan terus dipertahankan, mengingat Indeks Kepuasaan Masyarakat (IKM) ini merupakan indikator kinerja berbasis Balanced ScoreCard pada Bappenda, khususnya Bidang Pengendalian dan Pembinaan. 


\section{SIMPULAN}

Dari hasil penulisan laporan praktek kerja lapangan (PKL) yang dilaksanakan pada kantor Badan Pengelolaan Pendapatan Daerah Provini NTB Mataram kurang lebih selama 2 (dua) bulan. Maka penuis mengambil kesimpulan antara lain:

1. Pelaksanaan Pajak Kendaraan Bermotor pada Kantor Badan Pengelolaan Pendapatan Daerah Provinsi NTB menyediakan pelayanan yang mudah dan cepat wajib pajak dalam pembayaran Pajak Kendaraan Bermotor, yang terdiri dari dari Samsat Drive Thru, Samsat Keliling dan Samsat Delivery.

2. Pajak Kendaraan Bermotor (PKB) adalah pajak atas kepemilikan dan/atau penguasaan kendaraan bermotor, mengenai sistem dan prosedur PKB saat ini didasarkan pada dasar hukum yang jelas dan kuat sehingga harus dipatuhi oleh masyarakat dan pihak yang terkait, begitupun objek dan subjek PKB itu sendiri.

3. Prosedur pemungutan dan prosedur pelayanan Pajak Kendaraan Bermotor adalah sub sector pajak daerah yang berasal dari Pajak Kendaraan Bermotor (PKB), sistem pengelolaan penerimaannya dilakukan dalam Sistem Administrasi Manunggal (SAMSAT), Pajak Kendaraan Bermotor yang sumber pendapatannya dalam bentuk pajak yang dipungut atas kepemilikan dan/atau penguasaan kendaraan bermotor. 


\section{DAFTAR PUSTAKA}

Anonim, Buku Pedoman "Praktek Kerja Lapangan 'Program D-III Perpajakan Fakultas Ekonomi dan Bisnis Universitas Mataram 2020.

Anonim, "Undang-Undang Republik Indonesia Nomor 28 Tahun 2009 tentang Pajak Daerah dan Retribusi"

Darwin, 2010, "Pajak Daerah dan Retribusi" edisi, Mitra Wacana Media, Jakarta

Mardiasmo, 2018. Perpajakan Indonesia, Buku terbaru. Jakarta: Penerbit Andi

Resmi, Siti. 2007. Perpajakan Teori Dan Kasus, Edisi Delapan. Yogyakarta: Penerbit Salemba Empat.

Resmi, Siti. 2017. Perpajakan Indonesia, Edisi Sepuluh. Yogyakarta Penerbit Salemba Empat

Peraturan Daerah Provinsi Nusa Tenggara Barat "Perda Nomor 1 Tahun 2011 Tentang Pajak Daerah".

Peraturan Gubernur Nusa Tenggara Barat "Pergub Nomor 2 Tahun 2012 Tentang Pelaksanaan Peraturan Daerah Provinsi Nusa Tenggara Barat dan Nomor 1 Tahun 2011 Tentang Pajak Daerah". 